\title{
Fermentation of Prawn Waste by using Effective Microorganism (EM) for Protein Production
}

\author{
Nor Masdiana Zulkeple ${ }^{1}$, Zainoha Zakaria ${ }^{1 *}$, Salehhuddin Hamdan ${ }^{2}$, Mohammed Suhaimee Abdul Manaf ${ }^{3}$ \\ ${ }^{1}$ Department of Chemistry, Universiti Teknologi Malaysia, Johor, Malaysia \\ ${ }^{2}$ Department of Biology, Universiti Teknologi Malaysia, Johor, Malaysia \\ ${ }^{3}$ Brakishwater Aquaculture Research Centre, 81550 Gelang Patah, Johor, Malaysia \\ Received 10 July 2011, Revised 31 August 2011, Accepted 15 September 2011, Available online 3 December 2011
}

\begin{abstract}
Effective microorganisms or EM has been actively used for various reasons but mainly in the waste water treatment, as plant growth initiators and fertilizers. In this study, fermentations of local tiger prawn waste (Panaeus monodon) by EM were conducted at laboratory scale at different fermentation conditions for protein recovery. Fermentations were conducted at various temperature conditions $\left(25^{\circ} \mathrm{C}, 37^{\circ} \mathrm{C}\right.$ and $\left.60^{\circ} \mathrm{C}\right)$ and various level of inoculum and carbohydrate source $(5 \%, 10 \%, 15 \%$ and $20 \%)$ and their $\mathrm{pH}$ values compared over 72 hours. Results showed that the $\mathrm{pH}$ rapidly decreased to $\mathrm{pH} 5.0$ and the fermentation profiles were similar when different types of carbohydrates were used during fermentation. However, temperatures affect fermentations considerably where the $\mathrm{pH}$ did not rapidly decrease at $60^{\circ} \mathrm{C}$. The fermentation products or silage formed is also stable over a period of 60 days. In addition, acid production was dependent on glucose concentration but not on the inoculum level. For protein production, approximately $86 \%$ of protein can be recovered after fermentation process. Therefore, it can be suggested that fermentations were successful using EM on palm brown sugar and fermentation done at either $25^{\circ} \mathrm{C}$ or $37^{\circ} \mathrm{C}$ due to its better acid production.
\end{abstract}

| Fermentation | Effective microorganism | Prawn waste |

(B) 2011 Ibnu Sina Institute. All rights reserved. http://dx.doi.org/10.11113/mjfas.v7n2.247

\section{INTRODUCTION}

In Malaysia, the production of prawn is very high as opposed to crab [1]. Prawn is rich in protein, calcium, vitamins, and various extractable compounds and has been used as one of the most popular raw material for food industry. Generally, the head, shell and tail portions of prawn are removed during processing and these account for approximately $50 \%$ of the catch. Recently with the rapid growth of the fast food industry, consumption of prawn has increased and thus increasing the waste too. Several studies have been done to find ways for greater utilization of prawn processing by-products in order to improve income as well as reducing potential environmental pollution due to waste dumping [2].

Prawn by-products can be one of the potential animal protein source and also important source of chitin and asthaxanthin [3]. Researchers have commonly utilized traditional method where acid and alkali were used (usually $4 \%$ sodium hydroxide and $4 \%$ hydrochloric acid) for deproteination and demineralization, making this process aggressive and give bad effect to the environment [4].

Corresponding author at: Department of Chemistry, Faculty of Science, Universiti Teknologi Malaysia, 81310 UTM Skudai, Johor, Malaysia

E-mail addresses: zainoha@kimia.fs.utm.my (Zainoha Zakaria)
As a substitute to the chemical and enzymatic process, a biological process has been introduced for deproteination and demineralization. Fermentation represents a cheap technique which will stabilize and retain the nutritional quality of the by-products [5].Work done by Nor et al. (2011) [6], showed that protein obtained through fermentation of tiger prawn waste can partially replace the imported fishmeal in the seabass diet. Similar fermentation approach involving lactic acid bacteria (LAB) was used to ferment prawn waste (scampi) which has been proven successful to recover both protein and chitin $[7,8]$. The basic principles of fermentation are carbohydrate source and lactic acid bacterial starters. Researchers working on shrimp waste fermentation have reported varying levels of fermentation conditions $[4,6,9,10]$. This includes sugar levels varying from 5 to $20 \%$, inoculum levels varying from 5 to $20 \%$ and incubation time ranging between 3 days to 7 days. During the fermentation, acid is being produced by the bacteria, thus reacting with the calcium carbonate in the waste and at the same time preserving the product which is highly perishable. In the acid condition, the proteolytic enzymes from the visceral prawn head fraction are actively solubilising the protein from the waste, which in turn produces a thick protein rich brownish liquor. However, maintaining $\mathrm{LAB}$ as the starter cultures require good handling and needs good refrigeration facilities. Recent development of using effective microorganisms (EM) in various sectors especially in waste treatments has prompted 
this work to apply EM to ferment prawn waste in order to obtain a probiotic-rich protein. Furthermore EM technology has been commercialized and is easy to use. Many research articles showed EM has been successfully used in composting, cleaning up polluted rivers and promote plant growth [11-13]. Basically, EM contains $\mathrm{LAB}$, yeast, actinomycetes and photosynthetic bacteria. It has been reported to be able to reduce foul smell in rubbish dumps, clean pollution, and initiates growth of plants.

Protein from prawn has been proven to contain high quality amino acid content important both as feed attractant, and has easily digestible protein [14]. The use of extracted protein as opposed to using whole waste is to avoid using a high fibre protein in the fish diet which will make the feed highly indigestible [15]. Since prawn waste protein is cheaper to obtain, it is expected to be economically viable to be used in diets for carnivorous fish such as Siakap (Lates calcarifer) which requires about $45 \%$ protein-based diet [16]. In recent years, aquaculture feed pellet depended much on the imported fish meal which has high quality protein but its use is currently limited because of the increasing price over the world. If alternative protein sources are being produced on a larger scale to replace costly fishmeal, it is an advantage to aquaculture sector.

\section{EXPERIMENTAL}

\subsection{Inoculum preparation}

Two types of effective microorganism (EM) were used as starter cultures (EM from Malaysia (EM2) and EM from Indonesia (EM4). They were supplied by animal tissue culture laboratory, faculty of Bioscience and Biotechnology, Universiti Teknologi Malaysia.

\subsection{Prawn Waste}

Frozen tiger prawn waste (Penaeus monodon) was obtained from a local prawn processing industry in Johor. The prawn wastes consisted of head, exoskeleton, and tail portion were minced through a $4.5 \mathrm{~mm}$ die plate using an industrial mincer (Rheninghaus Meat Mincer, model EVE/ALL 22, Italy) and stored in plastic bags at $-20^{\circ} \mathrm{C}$ until further use for fermentation purpose.

\subsection{Media and carbohydrate source for Bacteria}

EM was activated (EM-A) using distilled water and brown palm sugar in a ratio of 1:20:1 [17] for a week prior to use. Glucose (Merck, Germany) and brown palm sugar purchased from a local market were used as a source of carbohydrate for bacteria and EM.

\subsection{Fermentation of Prawn Waste (optimization of carbohydrate source and temperature)}

Fermentation was carried out using thawed minced prawn waste $(100 \mathrm{~g}), 10 \%(\mathrm{w} / \mathrm{w})$ of carbohydrate sources (glucose, and brown palm sugar) and $10 \%(\mathrm{v} / \mathrm{w})$ inoculum (EM) in a covered bottle and was incubated at required different temperatures $\left(25^{\circ} \mathrm{C}, 37^{\circ} \mathrm{C}\right.$, and $\left.60^{\circ} \mathrm{C}\right)$ for 72 hours. Occasional stirring was provided especially during the first 24 hours and $\mathrm{pH}$ monitored using bench top $\mathrm{pH}$ meter (Hanna Instruments, Italy).

\subsection{Fermentation of Prawn Waste (optimization the level of carbohydrate and inoculum)}

Fermentation was carried out using thawed minced prawn waste $(100 \mathrm{~g})$, varying levels $(5 \%, 10 \%, 15 \%, 20 \%)$ of brown palm sugar (w/w) and 10\% EM (v/w) in a covered bottle and was incubated at $37^{\circ} \mathrm{C}$ for 72 hours. Occasional stirring was provided especially during the first 24 hours and $\mathrm{pH}$ monitored using bench top $\mathrm{pH}$ meter (Hanna Instruments, Italy).

\subsection{Stability Study of Fermented Prawn Waste}

Similar fermentations as section 2.4 were also carried out for prolong duration of up to 60 days to test for stability over long periods. Stability over prolonged duration is important for the sustainability for future large scale exercises. $\mathrm{pH}$ were monitored in duplicate samples at various intervals during the fermentation process.

\section{RESULTS \& DISCUSSION}

\subsection{Fermentation of prawn waste}

Unfermented prawn waste is best described as being in a moist semi-solid form which turned slurried within several hours of fermentation. EM-fermented prawn waste showed a good drop in $\mathrm{pH}$ values (Figure 1) during the first 24 hours of fermentation process. A fast decreased of $\mathrm{pH}$ value from $\mathrm{pH} 7$ to $\mathrm{pH} 5$ within 24 to $48 \mathrm{~h}$ indicates good fermentation silage and in the range recommended by Shahidi and Synowiecki (1991) [3]. The $\mathrm{pH}$ drop is due to the acid production as shown in Figure 2. After 24h the $\mathrm{pH}$ drop became more stable at $\mathrm{pH} 4$ and brownish liquor was increasingly being produced (Figure 3 ). Bubbles were also observed on the top layer of fermented slurry, and stirring process was provided occasionally to make sure the samples is homogeneous mixed to prevent spoilage which usually takes place on the top fractions where spoilage bacteria which is usually aerobic is more accessible to larger amount of oxygenated waste.

Lactic acid bacteria (LAB) is one of the most important species in EM. A study was conducted to see the LAB growth using MRS plate count and the results showed that LAB in EM fermented waste was high (Figure 4). The presence of $L A B$ species may be the reason for the slightly higher acidity in EM fermented waste (Figure 2). It may also because of other species within EM that promote acid production. Acid is very important in fermentation process, 
as it needed to either prevent the waste from spoilage and also to purify chitin of any minerals which is mostly calcium carbonates which formed bubbles during the fermentation due to production of carbon dioxide $\left(2 \mathrm{C}_{3} \mathrm{H}_{6} \mathrm{O}_{3}\right.$ $\left.+\mathrm{CaCO}_{3} \rightarrow \mathrm{Ca}\left(\mathrm{C}_{3} \mathrm{H}_{5} \mathrm{O}_{3}\right)_{2}+\mathrm{H}_{2} \mathrm{O}+\mathrm{CO}_{2}\right)[18]$.

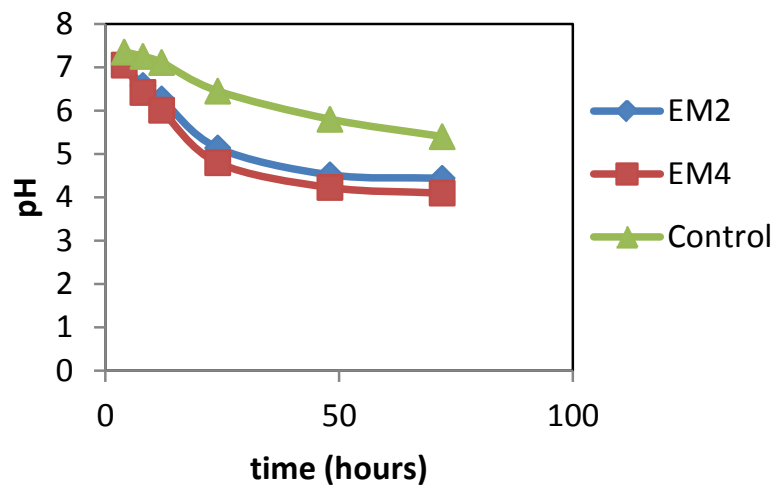

Figure 1.0: Effect of EM type on $\mathrm{pH}$ of fermented prawn waste at $37^{\circ} \mathrm{C}$ and brown palm sugar as carbohydrate source. Control sample did not contained EM.

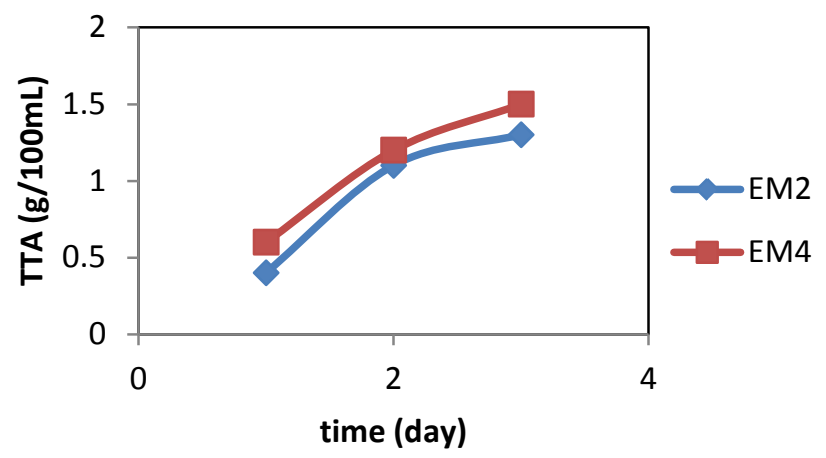

Figure 2.0: Titratable acidity profile during the fermentations of prawn waste using $\mathrm{EM}$ at $37^{\circ} \mathrm{C}$ and brown palm sugar as carbohydrate source.

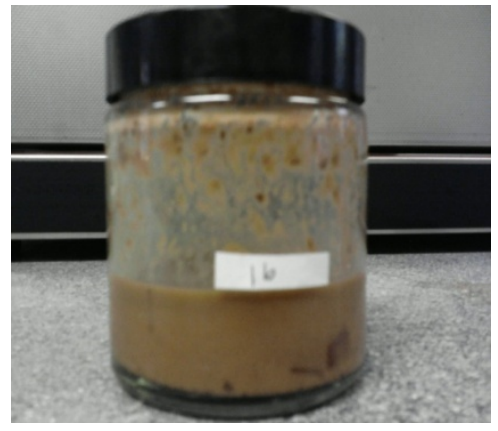

Figure 3.0: Fermented prawn waste silage after 72 hours fermentation producing a brownish proteinaceous liquor.

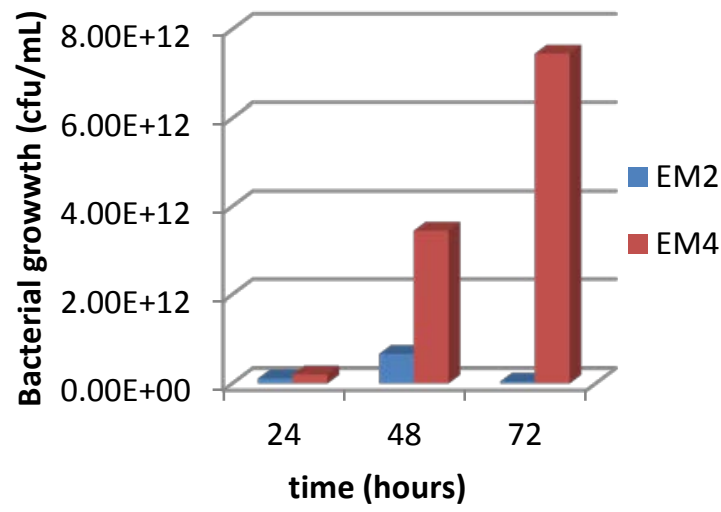

Figure 4.0: Effect of EM type on growth of LAB during fermentation of prawn waste.

\subsection{Effect of temperature on fermentation process}

Results showed that all samples were successfully fermented at $25^{\circ} \mathrm{C}$ and $37^{\circ} \mathrm{C}$. Rapid $\mathrm{pH}$ drops were noted within 12 hours to a $\mathrm{pH}$ of 4 and remain so until 72 hours (Figure 5). However at $60^{\circ} \mathrm{C}$, the samples did not ferment well as the $\mathrm{pH}$ not reached 5 after 72 hours duration. At higher temperatures, the organism in EM may not be at its optimum temperature as most of $\mathrm{EM}$ microbes are mesophilic. From the results, it showed that, $25^{\circ} \mathrm{C}$ and $37^{\circ} \mathrm{C}$ are the most suitable temperatures for fermentation to be monitored.

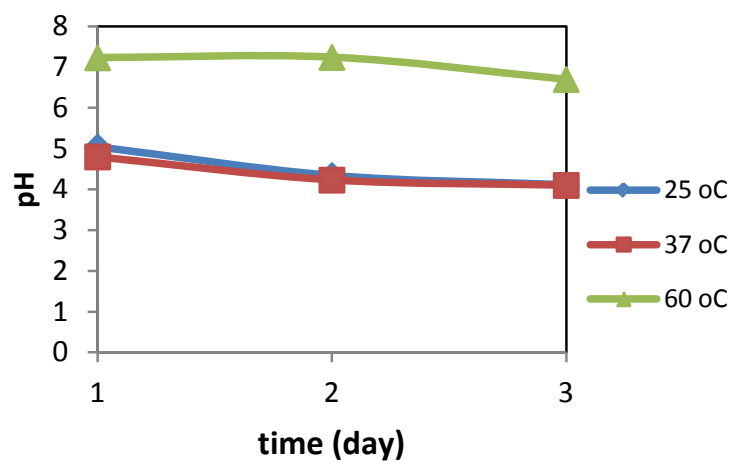

Figure 5.0: Effect of temperature on the fermentation of EM4-fermented prawn waste using brown palm sugar as the carbohydrate source.

\subsection{Effect of carbon source on fermentation process}

Result showed that both sugar sources (glucose and brown palm sugar) can be utilized to ferment prawn waste (Figure 6) without any effect on the $\mathrm{pH}$ drop. Carbohydrate source is vital for the growth of lactic acid bacteria and is also the growth component for EM cultures. Brown palm sugar is widely available and is economically viable on a larger scale. Usage of EM as a starter inoculum 
has the added advantage where it does not require refrigeration prior to use and it can be used up to one month after one to two weeks of activation process.

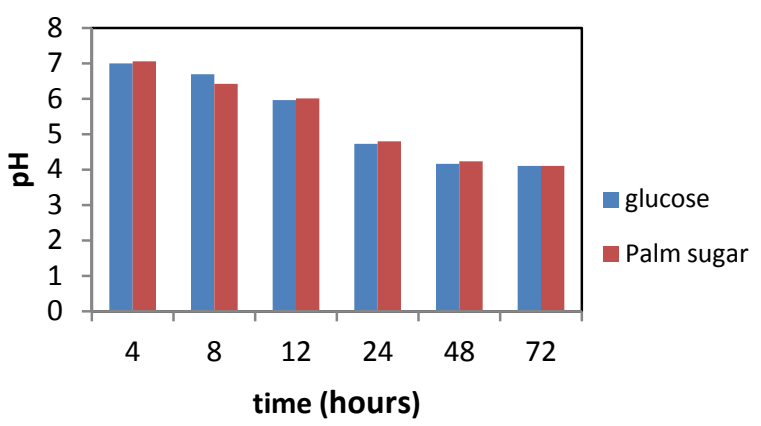

Figure 6.0: Effect of carbohydrate source on fermentation of prawn waste using $\mathrm{EM}$ at $37^{\circ} \mathrm{C}$.

\subsection{Effect of prolonged storage on stability of prawn waste silage}

A study of prolonged storage was carried out to observe the stability of prawn waste silage up to 60 days of fermentation process. From the observation there were no signs of spoilage or any significant changes on $\mathrm{pH}$ values except for temperature $37^{\circ} \mathrm{C}$ where the $\mathrm{pH}$ started to rise after 40 days (Figure 7). The stability in $\mathrm{pH}$ might be due to the buffering action of amino acid and other salts in the silage or probably due to the partial neutralization of the acid by calcium from chitin in the sediments [7]. In addition, besides LAB, other organisms in EM might play a role to stabilize the silage over long periods. The stability study is seen important for the real industry where unexpected situation might be occurring. The protein obtained might be unable to immediately process into other products such as aquaculture feed diet if the facilities and automations are limited.

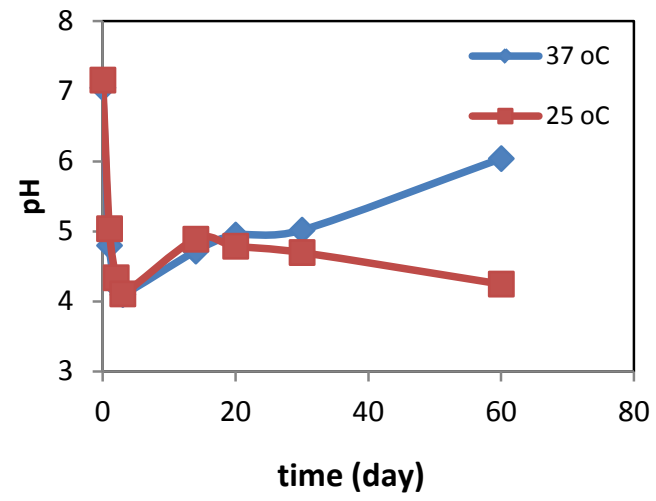

Figure 7.0: The $\mathrm{pH}$ profile of long term EM fermented prawn waste at various temperatures.

\subsection{Effect of levels of inoculum and carbohydrate source}

The quality of fermented tiger prawn waste products are dependent on the stages involve in fermentation process which is enzymatic protein degradation (deproteination) followed by minerals release (demineralization). The efficiency of the process was affected by inoculum levels supplied and levels of glucose which is important to demineralize the raw prawn wastes [19-21]. Result showed that inclusion of $5 \%$ inoculum of EM was enough to produce acceptable low $\mathrm{pH}$ drop after 72 hours of fermentation process (Figure 8). Figure 9 shows that the acid production is dependent on concentration and the $\mathrm{pH}$ value decreases fastest within 72 hours when the carbohydrate concentration is highest. However, most study utilized an intermediate value of inoculum size such a $10 \%$ $(\mathrm{v} / \mathrm{w})$ and a carbohydrate content of $10 \%(\mathrm{w} / \mathrm{w})$ for economical reason $[4,6,8,20,22]$. This is because, as long as the carbohydrate can support the bacterial growth, the fermentation can be done successfully.

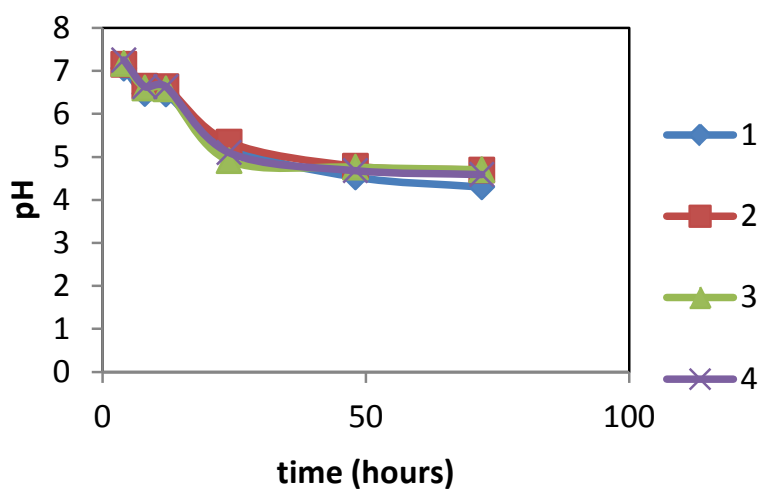

Figure 8.0: Effect of inoculum level on the fermentation of EM4-fermented prawn waste using brown palm sugar as the carbohydrate source. 1= 5\% of EM4, 2=10\% of EM4, $3=15 \%$ of EM4., $4=20 \%$ of EM4

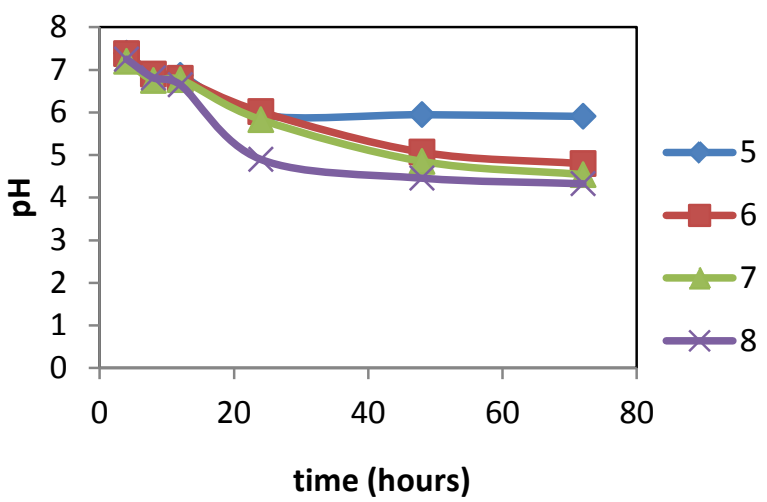

Figure 9.0: Effect of carbohydrate levels on the fermentation of EM4-fermented prawn waste using brown palm sugar as the carbohydrate source. $1:=5 \%$ of brown palm sugar, $2=$ $10 \%$ of brown palm sugar , $3=15 \%$ of brown palm sugar, $4=20 \%$ of brown palm sugar. 


\subsection{Protein production and proximate analysis on fermented liquor}

After 72 hours of fermentation process, the fermented prawn wastes were filtered to separate the solid and liquor part. The results from the proximate analysis showed that, $86 \%$ of protein can be recovered after fermentation process. Protein was produced due to the highly acidic environment. Acidic environment will denatured protein from the prawn waste forming a protein rich-liquor $[5,19]$ When protein denatures, it is susceptible to proteolytic digestion promoted by proteolytic enzyme (protease). This enzyme may come from the bacteria itself that secretes protease to hydrolyse or digest peptide bond in protein to its monomer or from the prawn waste which contains the guts and visceral.

\section{CONCLUSION}

This study shows that prawn waste can be successfully fermented using EM and is stable for 60 days, maintaining a low $\mathrm{pH}$ of within 4 to 5 . Fermentation process is best conducted at $37^{\circ} \mathrm{C}$ using $10 \%$ of $\mathrm{EM}$ and
$10 \%$ brown palm sugar as a cheap and easily available carbohydrate source. $86 \%$ of protein was recovered from the wastes and it is expected to further enhance production of protein on a larger scale by using automated bioreactors. Large scale production is economically viable provided that the source of waste is easily and cheaply available. The recovered protein can be incorporated as a cheap protein source in various animal feed preparations.

\section{ACKNOWLEDGEMENT}

The authors are grateful to the Ministry of Higher Education (MOHE), Malaysia for the financial support through the Fundamental Research Grant (FRGS, Vot 78545).

\section{REFERENCES}

[1] Annual Fisheries Statistic 2004. Malaysia: Malaysian Fisheries Department, 2004

[2] M. S. Heu, J. S. Kim, F. Shahidi, Food Chemistry, 82 (2003) 235-242

[3] F. Shahidi, and J. Synowiecki, Agric. Food Chem., 39 (1991) 1527-1532

[4] C. Bueno-Solano, J. Lopez-Cervantes, O. N. Campas-Baypoli, R. Lauterio-Garda, N. P., Adan-Bante and D. I. Sanchez-Machado, Food Chemistry, 112 (2009) 671-675

[5] O. Fagbenro, K. Jauncey, and G. Haylor, Aquat. Living Resour, 7 (1994) 79-85

[6] N. M. Nor, Z. Zakaria, M. S. A. Manaf, and M. M. Salleh, Applied Aquaculture, 23 (2011) 51-57

[7] G. M. Hall, S. D. Silva, INFOFISH Int., 2(1994) 27-30

[8] Z. Zakaria, , G.M. Hall and G. Shama, Process Biochemistry, 33 (1998) 1-6

[9] W. J. Jung, J. H. Kun, K. Y. Kim, and R. D. Park, Appl Microbial Biotechnol, 67 (2005) 851-854

[10] L. A. Cira, S. Huerta, G. M. Hall, and K. Shirai, Process Biochem., 37 (2002), 1359-1366

[11] C. K. Sung, S. Young-Chae, and K. In-Soo, Treatment of Food Waste Material by Effective Microorganisms and Its Use in Crop Production, Department of Environmental Engineering, Korea Maritime University, Pusan Korea, 2000

[12] A. Khaliq, M. Kaleem Abbasi, and T. Hussain, Bioresource Technology, 97 (2006) 967-972

[13] N. Szymanski, and R. A. Patterson, Effective Microorganisms (EM) and Wastewater Systems. Future Directions For On-Site Systems: Best Management Practice Proceedings of On-Site '03 Conference. $30^{\text {th }}$ September to $2^{\text {nd }}$ October 2003. University of New England, 347-354, 2003

[14] L. C. Nwanna, Pakistan Journal of Nutrition, 2 (2003) 339-345

[15] O. O. Oduguwa, A.O. Fanimo, V.O. Olayemi and N. Oteri, Arch. Zootec., 53 (2004) 87-90

[16] A. M. Mohammed Suhaimee, The Use of Protein from Palm Kernel Meal in the Diets of Seabass (Lates calcarifer). MSc. Thesis Universiti Teknologi Malaysia, 2006

[17] V. Sekeran, C. Balaji, T. Bagavathi Phuspa, Electronic Green Journal, 21(2005) 1

[18] G. M. Hall, and S. D. Silva, Lactic Acid Fermentation of Scampi (Penaeus monodon) Waste for Chitin Recovery, Elsevier Applied Science, London, 1992

[19] K. Shirai, I. Gurrero, S. Huetta, G. Saucedo, A. Castillo, O. Gonzalez, and G.M. Hall, Enzyme and Microbial Technology, 28 (2001) $446-452$

[20] M. S. Rao, J. Munoz, and W. F. Stevenns, Appl Microbial Biotechnol, 54 (2002) 808-813

[21] M. T. Madigan, J. M. Martinko, and J. B. Paker, Biology of Microorganism, ( $8^{\text {th }}$ ed), Englewood Cliffs: Prentice Hall, 1997

[22] A. Oyedapo, Fagbenro \& A. Oluayo,., and B. Olusoji, Food chemistry, 60 (1996) 489-493 